\title{
Influence of anaerobic fermentation of organic waste to change the content of biogenic elements in the effluent biogas plant
}

\author{
Skrylnyk Ye. ${ }^{1}$, Kutova A. ${ }^{2}$, Hetmanenko V. ${ }^{3}$ \\ National Scientific Center «Institute for Soil Science and Agrochemical Researches named after O.N. So- \\ kolovsky» \\ 4 Chaikovska Str., Kharkiv, 61024, Ukraine

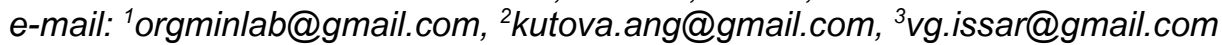

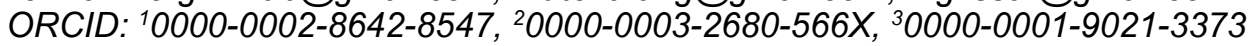

Goal. To establish the influence of anaerobic fermentation of plant and animal origin on changes in the content of biogenic elements in the liquid and solid fractions of effluent after the production of biogas. Methods. Analytical, calculation, mathematical-statistical. Results. It is established that the transformation of organic compounds in anaerobic fermentation process causes an alkaline reaction of biogas effluent. Comparing samples of the liquid fraction (fugate) and the solid fraction (digestat) of waste biogas production from different raw materials (bagasse, corn, and sorghum silage), it is determined that the content of nitrogen and potassium in the samples of discharge exceeds the corresponding figures of digestat, but the phosphorus content is higher in digestat (almost double). As to the content of biogenic elements the effluent after anaerobic fermentation of silo id better than the waste after processing the pulp. Liquid and solid fractions of the waste of biogas plant are enriched with ammonium nitrogen compared with the raw material more than on $40-60 \%$ (depending on raw material). Fugate contains less than $5 \%$ of solids and a major amount of potassium. Up to $80 \%$ of the mass fraction of nitrogen in fugate is in its ammonium form. On the background of low ash content of digestat the content of total carbon is high (over 30\%). Conclusions. The studied wastes of biogas plants which work on raw materials of plant and animal origin on agrochemical indicators are not worse than other raw materials and have a high fertilizing potential, especially in acidic soils, because of their alkaline reaction. Waste of biogas plants is characterized by low ash content and high content of total carbon, which confirms their value to potential humus creation ability in soils.

Key words: raw materials, total carbon, humus, digestat, fugate.

DOI: https://doi.org/10.31073/agrovisnyk202003-10

To date, in the face of an acute energy crisis, a promising area is the use of renewable energy sources. In some countries of the world, biomass energy has taken an important place in the energy balance. Overall, in the EU, $14 \%$ of total energy demand is generated annually from biomass. Anaerobic digestion is an effective way of processing biomass, since most of the energy in the feedstock is converted to methane and only a small portion is absorbed by the microorganisms. Biomass suitable for anaerobic digestion includes wastes from agriculture, the municipal sector with a high content of lignocellulose and the like. To date, China, India, Nepal and Japan are leading countries in the application of biogas technologies. In Ukraine, biogas technologies are being implemented much more slowly. It should be noted that there is no conventional name for biogas plants waste. In domestic and foreign literature, it is referred to in different terms: waste biogas plant solid and liquid fractions together (effluent), digestate, biogas sediment, bioslim, liquid product of centrifugation, which is released during dehydration of bulk material (fugate) and solid liquid fraction. The quality of effluent directly depends on the temperature regime of fermentation of biomass: thermophilic mode provides complete neutralization of pathogenic microorganisms and complete loss of germination of weed seeds.

Waste remaining after anaerobic digestion of raw materials is used as fertilizer [1, 2]. The fermented liquid residue is highly environmentally friendly because during the anaerobic digestion of organic raw materials the pathogenic microflora that is in the manure is destroyed, and the unpleasant odor is neutralized [3].

The estimation of potential fertilizers from effluent is given in a number of papers [4-11], but because of the wide variety of feedstock used in biogas production, the nitrogen content was significantly different [12].

In the studies of G. Qi, Z. Pan, Y. Sugawa et al. [13], the properties of fertilizers from cattle manure (cattle) obtained under mesophilic fermentation were compared. It was found that the properties of the effluent depend on the feedstock and the conditions of anaerobic digestion.

It has been proven that the use of efluent is an alternative to manure [14]. Efluent and manure samples were screened for bacteria that promote plant growth, nutrient content and heavy metals. Manure contained higher concentrations of heavy metals, phosphorus and potassium. The presence of a large amount of nitrogen, a lower content of heavy metals compared with cattle manure, as well as a significant number of bacteria that stimulate plant growth, confirms the potential ability of efluent to increase soil fertility.

Tarasov S.I., Kovalev D.A., Karaev Yu.V. [15], studies of the influence of thermophilic and mesophilic modes of operation of a biogas plant using various types of substrates (semi-liquid cattle manure, liquid pig manure, liquid bird droppings) on the agrochemical characterization of the effluent were carried out. It was 
established that the main humus-forming substances and nutrients of plants were preserved, despite the decrease in the content of organic matter. The influence of the temperature regime of anaerobic digestion on the change in the properties of the substrates has not been established.

It was found that the disinfecting effect is higher, the greater the temperature and residence time of the substrate in the reactor. Thus, the death of pathogens and parasites begins already during the mesophilic fermentation regimen $\left(33^{\left.-38^{\circ} \mathrm{C}\right)}\right.$ ) and reaches its maximum under the thermophilic regimen (53-55ㅇ) [16]. Therefore, BSU waste has a significant advantage as a raw material for organic fertilizer compared with compost, manure and fresh manure.

In this regard, the determination of the effect of anaerobic digestion on the change in the content of nutrients in the liquid and solid fractions from crop and livestock wastes is an important issue in agricultural production with a view to its further use in agriculture.

The purpose of the research - To determine the effect of anaerobic digestion of raw materials of plant and animal origin on the change in the content of biogenic elements in the liquid and solid fraction of effluent after the biogas process.

Materials and methods. Analytical work was carried out with samples of solid (digestate) and liquid (fugate) fraction of biogas plants (BSP) working on bagasse (1 BSP), maize silage (2 BSP) and dehydrated sludge mixed with sorghum silo and litter (3 BSP) and livestock waste (liquid pig manure and cattle manure):

bagasse, liquid fraction after separation, solid fraction after separation (1 biogas plant, processing of sugar production waste);

- $\quad$ corn silo, liquid fraction after separation, solid fraction after separation (2 biogas plant); plant) mixture of dehydrated sludge, sorghum silo and litter, liquid fraction, solid fraction (3 biogas

pig manure and cattle bed manure in a ratio of 1:4 before and after separation; pig manure and cattle liquid manure in a ratio of 1:10 before and after separation.

Samples of organic raw materials before and after anaerobic digestion were analyzed in a competent laboratory in triplicate (certificate of compliance of the measurement system with the requirements of DSTU ISO 10012:2005, № 01-0104/2017) according to the current regulatory and methodological documents: determination of moisture and dry residue according to DSTU EN 13040; ash determination according to DSTU EN 13039; determination of $\mathrm{pH}$ according to DSTU EN 13037; determination of the total mass fraction of nitrogen and the mass fraction of ammonium nitrogen according to DSTU 7911; determination of total phosphorus according to DSTU ISO 5316; determination of total potassium according to DSTU 7949; determination of total carbon according to DSTU 4289.

During the processing of analytical data, statistical and mathematical methods were used. Analysis of variance to calculate the reliability of research results.

Results. Biogas effluent is an organic mass with a moisture content of $63.5-99 \%$ with an alkaline reaction almost devoid of an unpleasant odor. The water $\mathrm{pH}$ of the samples for efluent from various raw materials is in the alkaline range: the fugate is characterized by a $\mathrm{pH}$ of $7.6-8.4$, and the digestate $-8.7-9.1$ (Table). The change in $\mathrm{pH}$ values in BGP waste is associated with the conversion of organic compounds and is determined by the balance of organic acids, ammonia, carbon dioxide.

Agrochemical composition of organic raw material, solid and liquid residue after anaerobic digestion

\begin{tabular}{|c|c|c|c|c|c|c|c|}
\hline \multirow{2}{*}{ Raw material } & \multirow{2}{*}{$\begin{array}{l}\text { Dry matter/dry } \\
\text { residue, \% }\end{array}$} & \multirow{2}{*}{$\mathrm{pH}$} & \multirow{2}{*}{$\begin{array}{c}\text { Ash } \\
\text { content, \% }\end{array}$} & \multirow{2}{*}{$\begin{array}{l}\mathrm{C}_{\text {tot }}, \\
\%\end{array}$} & \multicolumn{3}{|c|}{$\begin{array}{l}\text { Mass fraction of } \\
\text { total compounds, \% }\end{array}$} \\
\hline & & & & & $\underset{\text { aг }}{\mathrm{N}_{3}}$ & $\begin{array}{l}\mathrm{P}_{2} \\
\mathrm{O}_{5}\end{array}$ & $\mathrm{O}^{\mathrm{K}_{2}}$ \\
\hline Bagasse & 15,9 & 3,4 & 12,0 & $\begin{array}{l}30 \\
8\end{array}$ & $\begin{array}{c}0, \\
06 \\
0, \\
35\end{array}$ & $\begin{array}{c}0 \\
13 \\
0 \\
82\end{array}$ & $\begin{array}{c}0, \\
07 \\
0, \\
44\end{array}$ \\
\hline Liquid fraction (1 BGP) & 2,3 & 7,6 & 16,6 & $\begin{array}{l}11 \\
5\end{array}$ & $\begin{array}{l}0, \\
08\end{array}$ & $\begin{array}{l}0, \\
05 \\
\end{array}$ & $\begin{array}{c}0, \\
14 \\
\end{array}$ \\
\hline Solid fraction (1 BGP) & 24,2 & 8,7 & 12,5 & $3^{32}$ & $\begin{array}{c}0, \\
36 \\
1, \\
50\end{array}$ & $\begin{array}{c}0 \\
13 \\
0 \\
54\end{array}$ & $\begin{array}{c}0, \\
12 \\
0 \\
49\end{array}$ \\
\hline $\mathrm{LSD}_{05}$ & 0,33 & $\begin{array}{l}0,0 \\
8\end{array}$ & 0,20 & $\begin{array}{l}0,1 \\
5\end{array}$ & $\begin{array}{c}0, \\
01 \\
0 \\
04\end{array}$ & $\begin{array}{c}0 \\
02 \\
0 \\
01\end{array}$ & $\begin{array}{c}0, \\
01 \\
0 \\
01\end{array}$ \\
\hline Maize silage & 23,9 & 3,5 & 5,5 & $5^{36}$ & $\begin{array}{c}0, \\
06 \\
0, \\
23\end{array}$ & $\begin{array}{c}0 \\
05 \\
0 \\
21\end{array}$ & $\begin{array}{c}0 \\
10 \\
0 \\
42\end{array}$ \\
\hline
\end{tabular}




\begin{tabular}{|c|c|c|c|c|c|c|c|}
\hline Liquid fraction (2 BGP) & 5,3 & 7,8 & 18,5 & 20 & 36 & 16 & $29^{0,}$ \\
\hline Solid fraction (2 BGP) & 21,3 & 8,8 & 7,5 & $\begin{array}{l}31 \\
5\end{array}$ & $\begin{array}{c}0, \\
25 \\
1, \\
18\end{array}$ & $\begin{array}{c}0, \\
23 \\
1, \\
08\end{array}$ & $\begin{array}{c}0 \\
26 \\
1, \\
22\end{array}$ \\
\hline $\operatorname{LSD}_{05}$ & 0,26 & $\begin{array}{l}0,1 \\
5\end{array}$ & 0,19 & $\begin{array}{l}0,2 \\
6\end{array}$ & $\begin{array}{c}0, \\
02 \\
0, \\
01\end{array}$ & $\begin{array}{c}0, \\
01 \\
0, \\
01\end{array}$ & $\begin{array}{c}0, \\
02 \\
0, \\
02\end{array}$ \\
\hline $\begin{array}{l}\text { Mixture of dehydrated } \\
\text { sludge, sorghum silage, litter } \\
\text { (3 BGP) }\end{array}$ & 31,5 & 5,3 & 8,7 & $\begin{array}{l}39 \\
0\end{array}$ & $\begin{array}{c}0, \\
83 \\
2, \\
18\end{array}$ & $\begin{array}{c}0 \\
49 \\
1, \\
28\end{array}$ & $\begin{array}{c}0 \\
60 \\
1 \\
68\end{array}$ \\
\hline Liquid fraction & 3,7 & 8,4 & 14,3 & 6,8 & $\begin{array}{l}0 \\
70\end{array}$ & 23 & 42 \\
\hline Solid fraction & 36,5 & 9,1 & 8,0 & $\begin{array}{l}33 \\
5\end{array}$ & $\begin{array}{c}0 \\
56 \\
1 \\
53 \\
\end{array}$ & $\begin{array}{c}2, \\
43 \\
6, \\
65\end{array}$ & $\begin{array}{c}0 \\
38 \\
1, \\
04\end{array}$ \\
\hline $\mathrm{LSD}_{05}$ & 0,59 & $\begin{array}{l}0,1 \\
9\end{array}$ & 0,24 & $3^{0,1}$ & $\begin{array}{c}0, \\
02 \\
0, \\
02\end{array}$ & $\begin{array}{c}0, \\
02 \\
0 \\
03\end{array}$ & $\begin{array}{c}0, \\
01 \\
0 \\
01\end{array}$ \\
\hline $\begin{array}{l}\text { Pig manure and cattle } \\
\text { manure }(1: 4)\end{array}$ & 23,9 & 9,1 & 34,3 & $\begin{array}{l}30 \\
0\end{array}$ & $\begin{array}{c}0, \\
53 \\
2 \\
22\end{array}$ & $\begin{array}{c}0, \\
34 \\
1, \\
42\end{array}$ & $\begin{array}{c}0, \\
90 \\
3, \\
74\end{array}$ \\
\hline Liquid fraction & 10,0 & 8,1 & 22,5 & $\begin{array}{l}37 \\
8\end{array}$ & 20 & 0, & $\begin{array}{c}0 \\
16\end{array}$ \\
\hline $\mathrm{LSD}_{05}$ & 0,38 & $\begin{array}{l}0,1 \\
4\end{array}$ & 0,43 & $\begin{array}{l}0,2 \\
9\end{array}$ & $\begin{array}{l}0, \\
01\end{array}$ & $\begin{array}{l}0, \\
02\end{array}$ & $\begin{array}{l}0, \\
01\end{array}$ \\
\hline $\begin{array}{l}\text { Pig manure and cattle } \\
\text { manure }(1: 10)\end{array}$ & 7,3 & 7,3 & 35,6 & - & 22 & 0 & 28 \\
\hline Liquid fraction & 1,0 & 7,6 & 37,5 & - & $\begin{array}{l}0 \\
06\end{array}$ & 04 & $\begin{array}{c}0, \\
12\end{array}$ \\
\hline $\mathrm{LSD}_{05}$ & 0,29 & $\begin{array}{l}0,2 \\
9\end{array}$ & 0,76 & - & 03 & 01 & 03 \\
\hline
\end{tabular}

The liquid fraction (fugate) contains less than $10 \%$ dry matter and the main amount of potassium. The nitrogen in the centrate is contained mainly in ammonium form (up to $80 \%$ of the mass fraction of total nitrogen). The liquid fraction of BSU working on corn silage has the largest number of macroelements. The corn silage fugate contained 6 times more total nitrogen, 3,2 times more phosphorus and 2,9 times more potassium compared to the feedstock. Fugate BGP, working on pulp, contained in its composition twice as much potassium compared to the feedstock.

The disposal of waste by the method of anaerobic digestion eliminates the wastewater of livestock complexes from the category of hazardous and obtain secondary raw materials in the form of liquid organic fertilizer. The manure of pigs and liquid manure of cattle was characterized by a low content of total nitrogen, phosphorus and potassium. The pig manure and litter manure of the cattle compared to the liquid manure contained three times more nitrogen and phosphorus in its composition.

The solid fraction after separation of the effluent contains about $30 \%$ water and is characterized by high $\mathrm{pH}$ (8.7-9.1) and low ash content (7.5-12.5\%). The nitrogen content in the digestate samples after processing various raw materials is almost the same at the level of $1.5 \%$ on a dry matter basis, the ammonium form is about half of the total nitrogen.

The total phosphorus content varies from $0.54 \%$ in dry matter in the digestate after anaerobic digestion of the pulp and up to $1.08 \%$ in the digestate from maize silage. The phosphorus content in the digestate from sorghum silage with the addition of sludge and litter was $0.63 \%$ on a dry matter basis.

The solid fraction of waste from BGP is depleted in potassium in comparison with the liquid fraction. Pulp digestate is characterized by the lowest potassium content $(0.49 \%$ by dry matter). About $1 \%$ of the total nitrogen, phosphorus, and potassium is contained in the digestate after anaerobic digestion of maize silage; pulp digestate was characterized by the least amount of total phosphorus and potassium. The solid fraction of 
BGP, working on a mixture of dehydrated sludge, sorghum silage, litter was characterized by the highest content of total nitrogen and phosphorus.

Against the background of low ash content, digestate has a high content of total carbon (more than 30\%). After processing the pulp, the efluent in the liquid fraction contains $11 \%$ of total carbon, after fermentation of corn silage $20 \%$. The liquid fraction of pig manure and cattle litter manure and the solid mixture fraction (dehydration sludge, sorghum with litter) (3 BGP) in their composition contained a large amount of total carbon from the investigated raw materials.

It was found that after anaerobic digestion, the liquid and solid fractions formed after separation are enriched with ammonium nitrogen (the nitrogen form most accessible to plants) as compared to the feedstock.

The liquid and solid fractions of bagasse and maize silage contained 0.13$0.2 \%$ ammonium nitrogen (per raw material), while the feedstock contained no more than $0.02-0.03 \%$. The ammonium form of nitrogen is formed as a result of the decomposition of nitrogenous organic compounds of the feedstock. The liquid and solid fractions of the mixture dehydrated sludge, sorghum silage with litter after separation were also characterized by an increase in the content of ammonium nitrogen by $42.9-60 \%$ compared with the feedstock.

Based on the generalization of the results of studies on the agrochemical composition of the liquid and solid fractions of BGP proved the possibility of their effective use in the production of organic fertilizers. One tonne of fugate contains 0,6 to $7 \mathrm{~kg}$ of nitrogen, 0,4 to $2,3 \mathrm{~kg}$ of phosphorus, 1,2 to 4,2 potassium, and 68 to $204 \mathrm{~kg}$ of carbon. From one tonne of digestate, 11,8 to $15,3 \mathrm{~kg}$ of nitrogen, 5,4 to $66,5 \mathrm{~kg}$ of phosphorus, 4,9 to $12,2 \mathrm{~kg}$ of potassium, 315 to $335 \mathrm{~kg}$ of carbon are supplied to the soil.

Waste biomass from biogas plants is recommended to be used as an organic fertilizer by combining a centrate or digestate with organic components. As additional components, it is recommended to use clay minerals (bentonite), solid or liquid animal waste (manure, litter), if necessary, moisture-absorbing material (peat, straw) and the addition of microorganisms from a certain temperature regime (not more than $60{ }^{\circ} \mathrm{C}$ ) to preserve biologically active substances from thermal destruction. If necessary, solid particles of spent biomass and organic raw materials are crushed using hammer mills, and controlled air conditioning is carried out. In the manufacture of organic fertilizers, it is necessary to observe the ratio of liquid/solid fraction of BGP waste at a level of 1-1,5.

Organic fertilizers based on BGP waste are characterized by significant fertilizing potential and will be effective if applied on medium and slightly acidic soils (with $\mathrm{pH}$ 4.6-5.0 and 5.1-5.5) for winter wheat, buckwheat, soy and vegetable crops (cabbage, onions, cucumbers, carrots, tomatoes).

\section{Conclusions}

Agrochemical characteristic of effluent of biogas plants which processing different raw materials of plant and animal origin points significant fertilizing potential, especially on acid soils, due to alkaline reaction of effluent. The content of nitrogen and potassium in the samples of fugate exceeds the corresponding digests, but the content of phosphorus is higher in the solid fraction (almost 2 as much) was determined. By the content of biogenic elements in effluent from the anaerobic digestion of maize silage better than effluent from the anaerobic digestion of bagasse. Effluent from the biogas process is characterized by low ash content and high total carbon content $(37,8 \%)$ that confirms their value for potential humus formation in soil.

\section{Referances}

1. Arthurson, V. (2009). Closing the global energy and nutrient cycles through application of biogas residue to agricultural land - potential benefits and drawbacks. Energies, 2, $226-242$. doi.org/10.3390/en20200226.

2. Seadi, T. Al., \& Lukehurst, C. T. (2012). Quality management of digestate from biogas plants used as fertilizer. IEA Bioenergy.

3. Sadchikov, A. V. (2017). Primenenie metanovogo e`fflyuenta dlya vosstanovleniya estestvennogo czikla agrogeosistem. [The use of methane effluent to restore the natural cycle of agrogeosystems]. The successes of modern science, 1, 72-76. [In Russian].

4. Kuszel, M., \& Lorencowicz, E. (2015). Agricultural use biogas degistate as a replacement fertilizers. Agricultural and Agricultural Science Procedia, 7, 119-124.

5. Cavalli, D., Cabassi, G., \& Borrelli, L. (2016). Nitrogen fertilizer replacement value of undigested liquid cattle manure and digestates. European Journal of Agronomy, 73, 34-41. doi: 10.1016/j.eja.2015.10.007.

6. Riva, C., Orzi, V., \& Carozzi, M. (2016). Short-term experiments in using digestate products as substitutes for mineral $(\mathrm{N})$ fertilizer: agronomic performance, odours, and ammonia emission impacts. Science of The Total Environment, 547, 206-214. doi.org/10.1016/j. scitotenv.2015.12.156.

7. Kumar, S., Malav, L. C., Malav, M. K. et al. (2015). Biogas Slurry: Source of Nutrients for Eco-frendly Agricultural

International Journal of Extensive Research, 2, 42-46.

8. Helias, A., \& Brockmann, D. (2014). Use of fertilizing residues by agricultural activities in LCA studies. Proceedings of the $9^{\text {th }}$ International Conference on Life Cycle Assessment in the Agri-Food Sector. (pp. 523532). 
9. Alfa, M. I., Adie, D. B., Igboro, S. B. et al. (2014). Assessment of biofertilizer quality and health implications of anaerobic digestion effluent of cow dung and chicken droppings. Renewable Energy, 63, 681686. doi: 10.1016/j.renene.2013.09.049.

10. Comparetti, A., Febo, P., \& Greco, C. (2013). Current state and future of biogas and digestate production. Bulgarian Journal of Agricultural Science, 19(1), 1-14.

11. Eickenscheidt, T., Freibauer, A., Heinichen, J. et al. (2014). Short-term effects of biogas digestate and cattle slurry application on greenhouse gas emissions affected by $\mathrm{N}$ availability from grasslands on drained fen peatlands and associated organic soil. Biogeosciences, 11(12), 6187-6207. doi: 10.5194/bg-11-61872014.

12. Song, T. A., Dragicevic, I., Linjordet, R. et al. (2018). Recycling of biogas digestates in plant production: NPK fertilizer value and risk of leaching. International Journal of Recycling of Organic Waste in Agriculture, 7(1), 49-58. doi: 10.1007/s40093-017-0188-0.

13. Qi, G., Pan, Z., Sugawa, Y. et al. (2018). Comparative fertilizer properties of digestates from mesophilic and thermophilic anaerobic digestion of manure: focusing on plant growth promoting bacteria (PGPB) and environmental risk. Journal of Material Cycles and Waste Management, 1-10.

14. Mukhuba, M., Roopnarain, A., Adeleke, R. et al. (2018). Comparative assessment of bio-fertilizer quality of cow dung and anaerobic digestion effluent. Cogent Food \& Agriculture, 4, 14-35.

15. Tarasov, S. I., Kovalev, D. A., \& Karaeva, Yu. V. (2018). Primenenie e'fflyuenta biogazovoj ustanovki $v$ kachestve udobreniya dlya organicheskogo zemledeliya [The use of biogas plant effluent as a fertilizer for organic farming]. Bulletin of the Ulyanovsk State Agricultural Academy, 1, 91-97. doi: 10.18286-1816-45012018-3-91-97. [In Russian].

16. Macadi, M., Tomocsik, A., \& Orocz, V. (2012). Digestate: A New Nutrient Sourse - Review. Biogas. Croatia: InTech. (pp. 295-310). 